\title{
ANALISIS KEMAMPUAN PEMECAHAN MASALAH SD PADA MATERI KPK DAN FPB
}

\author{
Mamay Meilani', Anti Maspupah² \\ ${ }^{1,2}$ IKIP Siliwangi, Jl. Terusan Jendral Sudirman, Cimahi tengah, Kota Cimahi, Jawa Barat \\ berywae@gmail.com
}

\begin{abstract}
The study aims to analyze students' mathematical problem solving abilities in solving questions on the KPK and FPB material. This research is located at the Private Madrasah Ibtidaiyah Bongas 1. The research was conducted on October 7, 2019. The time was carried out when the Mathematics subject was in progress. This research was carried out specifically in class VI of Private Madrasah Ibtidaiyah Bongas 1 with a total of 25 students. This type of research is descriptive qualitative. Instrument is a tool used in collecting data to obtain data needed in a study. The instrument used in the study was a test in the form of 5 questions. Data analysis was carried out during and after data collection. The qualitative part is used to analyze students' learning difficulties when working on FPB material problems. Based on the results of the answers and interviews with students of Class VI Madrasah Ibtidaiyah Private Bongas 1, it can be concluded that (1). Students are not familiar with problem solving problems. (2). Students do not understand the steps in solving problem solving problems. (3) Students from the beginning did not know how to work on questions about FPB and KPK (4). Students find it difficult to work on FPB problems because students cannot perform multiplication and distribution operations which are prerequisite material from the KPK and FPB.
\end{abstract}

Kata kunci: Problem Solving Ability, KPK and FPB

\begin{abstract}
Abstrak
Penelitian ini bertujuan untuk menganalisis kemampuan pemecahan masalah matematis siswa dalam menyelesaikan soal pada materi KPK dan FPB. Penelitian ini bertempat di Madrasah Ibtidaiyah Swasta Bongas 1. Penelitian dilakukan pada tanggal 7 Oktober 2019. Waktu pelaksanakan dilakukan pada saat mata pelajaran Matematika sedang berlangsung. Penelitian ini dilaksanakan khusus pada kelas VI Madrasah Ibtidaiyah Swasta Bongas 1 dengan jumlah siswa sebanyak 25 siswa. Jenis penelitian ini adalah deskriptif kualitatif. Instrument adalah alat yang digunakan dalam mengumpulkan data untuk memperoleh data yang diperlukan dalam suatu penelitian. instrument yang digunakan dalam penelitian adalah tes berbentuk isian sebanyak 5 soal. Analisis data dilakukan selama dan sesudah pengumpulan data. Bagian kualitatif digunakan untuk menganalisis kesulitan belajar siswa dalam mengerjakan soal materi FPB. Berdasarkan hasil jawaban dan Wawancara dengan siswa kelas VI Madrasah Ibtidaiyah Swasta Bongas 1, dapat disimpulkan bahwa (1). Siswa belum terbiasa dengan soal pemecahan masalah. (2). Siswa tidak paham langkah-langkah dalam menyelesaikan soal pemecahan masalah. (3) Siswa dari awal memang tidak tahu cara mengerjakan soal tentang FPB dan KPK.(4). Siswa kesulitan dalam mengerjakan soal FPB karena siswa tidak dapat melakukan operasi perkalian dan pembagian yang merupakan materi prasyarat dari KPK dan FPB
\end{abstract}

Kata kunci: Kemampuan Pemecahan Masalah, KPK dan FPB.

Pembelajaran matematika di sekolah dasar tidak hanya ditujukan pada peningkatan kemampuan dalam berhitung atau menerapkan rumus dalam menyelesaikan soal-soal yang rutin saja. Pemecahan masalah merupakan salah satu aspek yang penting dalam pembelajaran matematika. Kemampuan pemecahan masalah sangat diperlukan siswa (Akbar, 2018; Chotimah, 2018), terkait dengan kebutuhan siswa untuk memecahkan masalah yang dihadapinya dalam kehidupan sehari-hari dan mempu mengembangkan diri mereka sendiri (Chotimah, 2018; Isnaeni, 2019; Nurhayati, 2019). Hal ini sejalan dengan Permendiknas RI No. 19 tahun 2005 tentang Standar Nasional Pendidikan pasal 1 No. 14, mata pelajaran matematika bertujuan agar siswa memiliki kemampuan sebagai berikut: (1) Memahami 
konsep matematika, menjelaskan keterkaitan antarkonsep dan mengaplikasikan konsep atau algoritma, secara luwes, akurat, efisien, dan tepat, dalam pemecahan masalah (Bernard \& Senjayawati, 2019), (2) Menggunakan penalaran pada pola dan sifat, melakukan manipulasi matematika dalam membuat generalisasi, menyusun bukti, atau menjelaskan gagasan dan pernyataan matematika (Fajriyah, 2019), (3) Memecahkan masalah yang meliputi kemampuan memahami masalah, merancang model matematika, menyelesaikan model dan menafsirkan solusi yang diperoleh, (4) Mengkomunikasikan gagasan dengan simbol, tabel, diagram, atau mesiswa lain untuk memperjelas keadaan atau masalah yang dapat diaplikasikan (Bernard, 2019; Wiliawanto, 2019), (5) Memiliki sikap menghargai kegunaan matematika dalam kehidupan, yaitu memiliki rasa ingin tahu, perhatian, dan minat dalam mempelajari matematika, serta sikap ulet dan percaya diri dalam pemecahan masalah.

Menurut Branca (1980 dalam Putra, 2018 :60) pemecahan masalah matematis merupakan salah satu kemampuan dasar yang harus dikuasai siswa karena dianggap sebagai jantungnya matematika dan menjadi inti utama dalam kurikulum matematika. Selanjutnya Ruseffendi (2006) mengemukakan bahwa kemampuan pemecahan masalah sangat penting dimiliki bagi mereka yang akan mempelajari matematika yang akan menerapkannya dalam bidang studi lain dan dalam kehidupan sehari-hari. Seperti halnya yang diungkapkan oleh Hasratuddin (2015) bahwa matematika adalah suatu sarana atau cara untuk menemukan jawaban terhadap masalah yang dihadapi manusia; suatu cara menggunakan informasi, manggunakan pengetahuan tentang bentuk dan ukuran, menggunakan pengetahuan tentang menghitung dan yang paling penting adalah memikirkan dalam diri manusia itu sendiri untuk melihat dan menggunakan hubungan-hubungan dari berbagai tahap (Timutius, 2018). Dalam standar isi pada Permendiknas No. 22 Tahun 2006 dinyatakan bahwa kemampuan pemecahan masalah matematika yang meliputi kemampuan memahami masalah, merancang model matematika, menyelesaikan model dan menafsirkan solusi yang diperoleh adalah salah satu dari tujuan mata pelajaran matematika.

Menurut Hamdani (Susilawati, 2014:16 dalam Ulvah, 2016:145-146) mengemukakan beberapa keunggulan dalam metode penyelesaian masalah. Diantaranya adalah sebagai berikut :
a. Melatih siswa untuk mendesain suatu penemuan
b. Berpikir dan bertindak kreatif
c. Memecahkan masalah secara realistis
d. Mengidentifikasi dan melakukan penyelidikan
e. Menafsirkan dan mengevaluasi hasil pengamatan
f. Merangsang kemajuan berpikir siswa untuk menyelesaikan masalah yang dihadapi dengan tepat
g. Dapat membuat pendidikan sekolah lebih relevan dengan kehidupan khususnya dunia kerja.

Menurut Sumarmo (2013:5) ada beberapa indicator dalam pemecahan masalah yaitu sebagai berikut :

a. Mengidentifikasi unsur-unsur yang diketahui, yang ditanyakan, dan kecukupan unsur yang diperlukan.

b. Merumuskan maslah matematika atau menyusun model matematika 
c. Menerapkan strategi untuk menyelesaikan berbagai masalah dalam atau diluar matematika

d. Menjelaskan atau menginterpretasikan hasil sesuai permasalahan awal

e. Menggunakan matematika secara bermakna

Dalam menyelesaikan soal pemecahan masalah, ada langkah-langkah kegiatan yang harus dilalui siswa . langkah - langkah kegiatan masalah menurut Polya (Soemarmo dan Hendriana, 2014:23) adalah sebagai berikut :

a. Memahami masalah

b. Merencanakan atau merancang strategi pemecahan masalah

c. Melaksanakan perhitungan atau menyelesaikan masalah

d. Memeriksa kembali kebenaran hasil atau solusi

Matematika adalah ilmu yang abstrak dan deduktif, sedangkan siswa Sekolah Dasar (SD) yang berusia pada usia 7 hingga 12 tahun masih berada pada tahap operasional konkrit yang belum dapat berpikir formal (UPI, 2007). Siswa yang sudah memiliki tahap berpikir normal (abstrak) dapat memahami konsep matematika dengan baik dibandingkan dengan siswa yang berada pada tahap berpikir operasi konkret. Penyajian bahan ajar yang tidak sesuai dengan perkembangan kemampuan siswa dapat mengakibatkan mereka kesulitan memahami konsep untuk menyelesaikan masalah karena siswa lebih kepaa konsep penghafalan (Puspitasari, 2019). Siswa terkadang merasa malas memecahkan masalah disebabkan kurangnya pengetahuan yang mereka miliki untuk menyelesaikannya (Rustyani, 2019). Pada umumnya di SD pembelajaran matematika yang mengembangkan kemampuan pemecahan masalah belum mendapat banyak perhatian dari guru-guru. Guru seringkali menekankan pada penyampaian materi pelajaran dan hitungan untuk menyelesaikan soal daripada memberikan situasi yang menekankan pada penguasaan kemampuan pemecahan masalah dengan membiasakan memberi masalah-masalah non-rutin yang menuntut siswa untuk berpikir menggunakan pengetahuan yang telah dimiliki sebelumnya untuk menyelesaikan masalah tersebut sehingga tidak ada lagi siswa yang tidak bisa menyelesaikan soal dengan alasan tidak tahu atau lupa.

Menurut Hadi \& Radiyatul (2014 dalam Putra, 2018:83) dan Nurianti, Halini, \& Ijudin (2015 dalam Putra, 2018:83) bahwa siswa cenderung menghafal rumus tanpa memahami konsep dan mengerjakan masalah matematika dengan ceroboh. Siswa lebih senang menggunakan cara yang singkat tanpa memperhatikan proses penyelesaian dengan benar. Apabila siswa menguasai konsep berarti mereka dapat memahami penggunaan konsep tersebut dalam menyelesaikan masalah.

KPK dan FPB merupakan salah satu materi yang menjadi masalah bagi siswa SD, termasuk siswa kelas VI MIS Bongas 1 Kecamatan Cililin Kabupaten Bandung Barat. Berdasarkan data yang didapat dari guru kelas VI MIS Bongas 1 Kecamatan Cililin Kabupaten Bandung Ba rat, siswa yang tidak lulus ulangan harian KPK dan FPB sebanyak 14 siswa (61\%) dari 25 siswa dengan batas kriteria ketuntasan minimum 65. Siswa agar dapat meyelesaikan masalah KPK dan FPB, dituntut untuk berkemampuan memecahkan masalah. Siswa dapat berkemampuan memecahkan masalah apabila siswa dapat menggunakan pengetahuan yang dimiliki sebelumnya serta proses pembelajaran dilakukan 
dengan pembelajaran yang tepat. Pembelajaran yang memberi peluang kepada siswa mempunyai kemampuan memahami masalah secara baik, merumuskan pemecahan masalah, melakukan pemecahan masalah, meninjau kembali dan mengambil keputusan akhir alternatif pemecahan yang paling efektif.

Menyimak uraian di atas dan berdasarkan hasil pekerjaan yang diperoleh dengan menggunakan tes yang diberikan kepada siswa kelas VI menunjukkan sebagian siswa masih cenderung mengalami kesulitan dalam menyelesaikan soal-soal, selain itu melalui wawancara dengan beberapa siswa, mengemukakan kesulitannya dalam mengerjakan soal yang dianggap sulit oleh siswa yaitu menyangkut materi Kelipatan Persekutuan Terkecil (KPK) dan Faktor Persekutuan Terbesar (FPB). Namun dalam hal ini belum diketahui secara mendalam tentang kesulitan yang siswalami siswa dalam menyelesaikan soal tersebut. Berdasarkan latar belakang di atas, maka tujuan dari penelitian ini untuk menganalisis kemampuan pemecahan masalah dalam menyelesaikan soal pada materi KPK dan FPB.

\section{METODE}

Tempat penelitian adalah tempat yang digunakan dalam melakukan penelitian untuk memperoleh data yang diinginkan. Penelitian ini bertempat di Madrasah Ibtidaiyah Swasta Bongas 1. Penelitian dilakukan pada tanggal 7 Oktober 2019. Waktu pelaksanakan dilakukan pada saat mata pelajaran Matematika sedang berlangsung. Penelitian ini dilaksanakan khusus pada kelas VIMadrasah Ibtidaiyah Swasta Bongas 1 dengan jumlah siswa sebanyak 25 siswa. Jenis penelitian ini adalah deskriptif kualitatif. Penelitian deskriptif adalah suatu bentuk penelitian yang paling dasar. Ditujukan untuk mendeskripsikan atau menggambarkan fenomena-fenomena yang ada, baik fenomena yang bersifat alamiah ataupun rekayasa manusia. Berdasarkan hal tersebut dapat dikemukakan bahwa metode penelitian kualitatif itu dilakukan secara insentif, peneliti ikut berpartisipasi lama di lapangan, mencatat secara hati-hati apa yang terjadi, melakukan analisis efektif terhadap berbagai dokumen yang ditemukan di lapangan, dan membuat laporan penelitian secara mendetail.

Instrument adalah alat yang digunakan dalam mengumpulkan data untuk memperoleh data yang diperlukan dalam suatu penelitian. instrument yang digunakan dalam penelitian adalah tes berbentuk isian sebanyak 5 soal (Terlampir). Analisis data dilakukan selama dan sesudah pengumpulan data. Bagian kualitatif digunakan untuk menganalisis kesulitan belajar siswa dalam mengerjakan soal materi KPK dan FPB.

Adapun pedoman penilaian didasarkan pedoman penskoran rubrik untuk kemampuan pemecahan masalah matematis yang dimodifikasi dari Sumarmo (1994, dalam Sendi Ramdhani 2012 : 46) melalui empat aspek Polya, sebagai berikut : 


\section{Tabel 1.}

Pedoman Penskoran Rubrik Tes Kemampuan Pemecahan Masalah Matematis

\begin{tabular}{|l|l|c|}
\hline \multicolumn{1}{|c|}{ Aspek yang Dinilai } & \multicolumn{1}{|c|}{ Reaksi Terhadap Soal/Masalah } & Skor \\
\hline \multirow{5}{*}{ Memahami Masalah } & Tidak memahami soal/tidak ada jawaban & 0 \\
\cline { 2 - 3 } $\begin{array}{l}\text { Merencanakan } \\
\text { Tidak memperhatikan syarat-syarat soal/cara } \\
\text { interpretasi soal kurang tepat }\end{array}$ & 1 \\
\cline { 2 - 3 } & Memahami soal dengan baik & 2 \\
\hline & Tidak ada rencana strategi penyelesaian & 0 \\
\cline { 2 - 3 } & Strategi yang direncanakan kurang tepat & 1 \\
\cline { 2 - 3 } & $\begin{array}{l}\text { Menggunakan satu strategi tertentu tetapi } \\
\text { mengarah pada jawaban yang salah }\end{array}$ & 2 \\
\cline { 2 - 3 } & $\begin{array}{l}\text { Menggunakan satu strategi tertentu tetapi tidak } \\
\text { dapat dilanjutkan }\end{array}$ & 3 \\
\cline { 2 - 3 } & $\begin{array}{l}\text { Menggunakan beberapa strategi yang benar } \\
\text { dan mengarah pada jawaban yang benar }\end{array}$ & 4 \\
\hline Menyelesaikan Masalah & Tidak ada penyelesaian & 0 \\
\cline { 2 - 3 } & Ada penyelesaian, tetapi prosedur tidak jelas & 1 \\
\cline { 2 - 3 } & $\begin{array}{l}\text { Menggunakan satu prosedur tertentu dan } \\
\text { mengarah pada jawaban yang benar }\end{array}$ & 2 \\
\cline { 2 - 3 } & $\begin{array}{l}\text { Menggunakan satu prosedur tertentu yang } \\
\text { benar tetapi salah dalam menghitung }\end{array}$ & 3 \\
\cline { 2 - 3 } & $\begin{array}{l}\text { Menggunakan prosedur tertentu yang benar } \\
\text { dan hasil benar }\end{array}$ & 4 \\
\hline Memeriksa Kembali & Tidak ada pemeriksaan jawaban & 0 \\
\hline & Pemeriksaan hanya pada perhitungan & 2 \\
\cline { 2 - 3 } & Pemeriksaan hanya pada proses & 3 \\
\cline { 2 - 3 } & Pemeriksaan pada proses dan jawaban & 2 \\
\hline
\end{tabular}

Berikut ini salah satu soal pemecahan masalah yang diberikan kepada siswa:

Bu Aminah mempunyai 20 jeruk dan 30 anggur. Jeruk dan anggur tersebut akan dimasukkan ke dalam plastic dengan jumlah yang sama besar. Cukupkah informasi di atas untuk menentukan banyaknya jeruk dan anggur pada masing-masing plastic? Berikan alasanmu!

\section{HASIL}

Tes yang diujikan berkenaan dengan materi KPK dan FPB. Aspek yang dinilai ada empat tahap, yaitu memahami masalah, merencanakan penyelesaian, menyelesaikan masalah, dan memeriksa kembali. Keempat tahap ini saling berkaitan antara satu dengan yang lain. Apabila siswa dapat mengerjakan tahap pertama, siswa akan dapat melanjutkan mengerjakan tahap kedua, ketiga, dan keempat. Berikut ini dijelaskan mengenai tahapan yang akan dilakukan siswa dalam menyelesaikan soal pemecahan masalah. 1. Tahap memahami masalah. Tahap ini bertujuan untuk mengetahui kemampuan siswa dalam memahami masalah ketika siswa dapat mengidentifikasi unsur unsur yang diketahui dan ditanyakan. 2. Tahap merencanakan penyelesaian. Tahap ini bertujuan untuk mengetahui kemampuan siswa apakah masalah yang terdapat dalam soal memakai konsep FPB ataukah KPK. 3. Tahap menyelesaikan masalah. Tahap ini bertujuan untuk mengetahui kemampuan siswa dalam 
mencari atau menentukan KPK dan FPB. 4. Tahap memeriksa kembali. Tahap ini bertujuan untuk mengetahui kemampuan siswa dalam menyimpulkan solusi dari masalah. Siswa diharapkan dapat menyimpulkan hasil penyelesaian dari informasi yang diperoleh pada tahap pertama, kedua, dan ketiga.

Pada Tabel berikut ini ditampilkan data banyak siswa yang menjawab soal pemecahan masalah dengan benar dan salah.

Tabel 2.

Persentase Jawaban Siswa pada Soal Pemecahan Masalah

\begin{tabular}{|c|c|c|c|c|c|c|c|c|c|c|}
\hline \multirow{3}{*}{$\begin{array}{c}\text { Aspek Yang } \\
\text { Dinilai }\end{array}$} & \multicolumn{10}{|c|}{ No. Soal } \\
\hline & \multicolumn{2}{|c|}{1} & \multicolumn{2}{|c|}{2} & \multicolumn{2}{|c|}{3} & \multicolumn{2}{|r|}{4} & \multicolumn{2}{|c|}{5} \\
\hline & B & $\mathbf{S}$ & B & $\mathbf{S}$ & B & $\mathbf{S}$ & B & $\mathbf{S}$ & B & $\mathbf{S}$ \\
\hline & $\begin{array}{l}7 \\
28 \%)\end{array}$ & $\begin{array}{c}18 \\
(72 \%)\end{array}$ & $\begin{array}{c}8 \\
(32 \%)\end{array}$ & $\begin{array}{c}17 \\
(68 \%)\end{array}$ & $\begin{array}{c}3 \\
(12 \%)\end{array}$ & $\begin{array}{c}22 \\
(88 \%)\end{array}$ & $\begin{array}{c}1 \\
(4 \%)\end{array}$ & $\begin{array}{c}24 \\
(96 \%)\end{array}$ & $\begin{array}{c}6 \\
(24 \%)\end{array}$ & $\begin{array}{c}19 \\
(76 \%)\end{array}$ \\
\hline & $\begin{array}{c}21 \\
(84 \%)\end{array}$ & $\begin{array}{c}4 \\
(16 \%)\end{array}$ & $\begin{array}{c}21 \\
(84 \%)\end{array}$ & $\begin{array}{c}4 \\
(16 \%)\end{array}$ & $\begin{array}{c}12 \\
(48 \%)\end{array}$ & $\begin{array}{c}13 \\
(52 \%)\end{array}$ & $(0 \%)$ & $\begin{array}{c}25 \\
(100 \%)\end{array}$ & $\begin{array}{c}7 \\
(28 \%)\end{array}$ & $\begin{array}{c}18 \\
(72 \%)\end{array}$ \\
\hline $\begin{array}{l}\text { Meny } \\
\text { Masa }\end{array}$ & $\begin{array}{c}8 \\
(32 \%)\end{array}$ & $\begin{array}{c}17 \\
(68 \%)\end{array}$ & $\begin{array}{c}14 \\
(56 \%)\end{array}$ & $\begin{array}{c}11 \\
(44 \%)\end{array}$ & $\begin{array}{c}17 \\
(68 \%)\end{array}$ & $\begin{array}{c}8 \\
(32 \%)\end{array}$ & $(0 \%)$ & $\begin{array}{c}25 \\
(100 \%)\end{array}$ & $\begin{array}{c}8 \\
(32 \%)\end{array}$ & $\begin{array}{c}17 \\
(68 \%)\end{array}$ \\
\hline $\begin{array}{l}\text { Mem } \\
\text { Kem }\end{array}$ & $\begin{array}{c}3 \\
(12 \%)\end{array}$ & $\begin{array}{c}22 \\
(88 \%)\end{array}$ & $\begin{array}{c}7 \\
(28 \%)\end{array}$ & $\begin{array}{c}18 \\
(72 \%)\end{array}$ & $(0 \%)$ & $\begin{array}{c}25 \\
(100 \%)\end{array}$ & $(0 \%)$ & $\begin{array}{c}25 \\
(100 \%)\end{array}$ & $\begin{array}{c}5 \\
(20 \%)\end{array}$ & $\begin{array}{c}20 \\
(80 \%)\end{array}$ \\
\hline Persentase & $39 \%$ & $61 \%$ & $50 \%$ & $50 \%$ & $32 \%$ & $68 \%$ & $1 \%$ & $90 \%$ & $26 \%$ & $74 \%$ \\
\hline
\end{tabular}

Tabel 2. menunjukkan bahwa dari 25 siswa, 3 orang yang dapat menjawab soal nomor 1, 7 orang yang bisa menjawab soal nomor 2, 5 orang yang bisa menjawab nomor 5, sedangkan untuk soal nomor 3 dan 4 tidak ada seorangpun siswa yang mampu menjawab dengan benar. Pada soal nomor 1 siswa banyak melakukan kesalahan dalam menjawab soal pada aspek memeriksa kembali yaitu sebesar 88\% kemusiswan diikuti kesalahan pada aspek memahami masalah, menyelesaikan masalah, dan merencanakan masalah, siswa banyak menjawab benar pada aspek merencanakan masalah sebesar $84 \%$. Pada soal nomor 2 siswa banyak melakukan kesalahan dalam menjawab soal pada aspek memeriksa kembali yaitu sebesar $72 \%$ kemusiswan diikuti kesalahan pada aspek memahami masalah, menyelesaikan masalah, dan merencanakan masalah, siswa banyak menjawab benar pada aspek merencanakan masalah sebesar $84 \%$.

Pada soal nomor 3 siswa banyak melakukan kesalahan dalam menjawab soal pada aspek memeriksa kembali yaitu sebesar 100\% kemusiswan diikuti kesalahan pada aspek memahami masalah, merencanakan masalah, dan menyelesaikan masalah masalah, siswa banyak menjawab benar pada aspek menyelesaikan masalah sebesar $68 \%$. Pada soal nomor 4 tidak ada seorangpun yang bisa menyelesaikan soal tersebut. Pada soal nomor 5 siswa banyak melakukan kesalahan dalam menjawab soal pada aspek memeriksa kembali yaitu sebesar $80 \%$ kemusiswan diikuti kesalahan pada aspek memahami masalah, merencanakan masalah, dan menyelesaikan masalah masalah, siswa banyak menjawab benar pada aspek menyelesaikan masalah sebesar 32\%. Dari uraian tersebut menunjukkan bahwa tahapan penyelesaian soal saling berkaitan dan semakin sukar untuk diselesaikan. Siswa dapat menyelesaikan masalah apabila mereka dapat memahami pertanyaan, melakukan perencanaan 
penyelesaian, memiliki kemampuan untuk menyelesaikan masalah, dan memeriksa kembali hasil yang diperoleh dengan benar.

Berikut ini ditampilkan salah satu contoh dari jawaban siswa yang mengalami kesalahan pada setiap aspek atau tahapan.

\section{$>$ Analisis Kesalahan Jawaban Siswa pada Tahap Pemahaman}

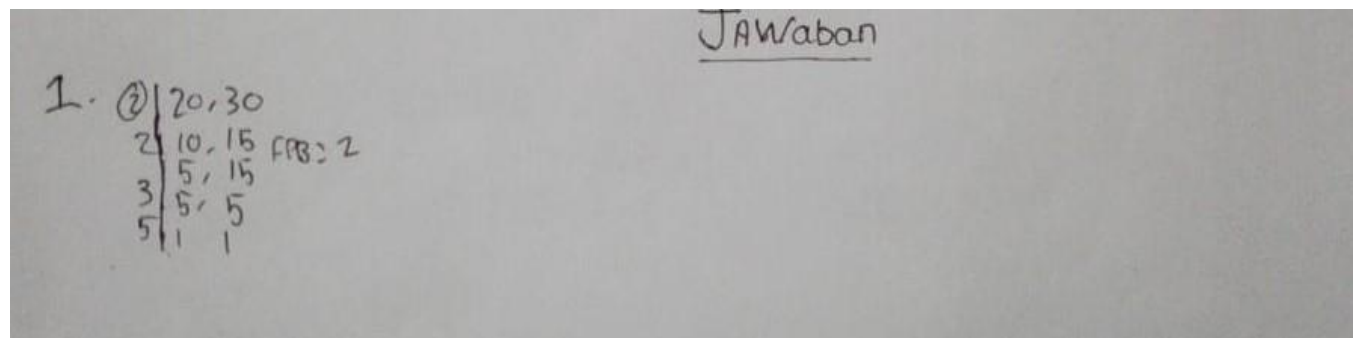

Gambar 1. Contoh jawaban siswa yang salah pada tahap memahami masalah.

Pada Gambar 1 terlihat bahwa siswa tidak mengerti pertanyaan pada soal dan belum memahami cara menyelesaikan soal. Pada lembar jawaban siswa hanya menuliskan secara langsung bahwa FPB nya adalah 2. Jawaban yang diberikan siswa tidak tepat. Berdasarkan wawancara, siswa tidak mengerti maksud dari soal, dan siswa tidak paham untuk menyelesaikan soal tersebut apakah menggunakan FPB atau KPK. Siswa belum paham tentang apa itu factor dan kelipatan serta perkalian dan pembagian yang merupakan materi prasyarat dari KPK dan FPB dimana hal tersebut mengakibatkan siswa tidak bisa menentukan KPK ataupun FPB. Siswa merasa tidak perlu untuk menuliskan unsur-unsur apa saja yang diketahui dari soal karena tidak mengerti. Siswa tidak pernah bertanya kepada guru ataupun temannya apabila siswa tidak mengerti suatu materi dengan alasan malu. Untuk jawaban yang tertera di lembar jawaban, untuk faktorisasi prima siswa melihat ke temannya dan hasil FPB siswa hanya menerka-nerka. Demikian juga untuk soal-soal yang lainnya. Siswa tidak begitu menyukai pelajaran matematika karena menurutnya terlalu sulit untuk dipahami dan memusingkan.

$>$ Analisis Kesalahan Jawaban Siswa pada aspek merencanakan penyelesaian.

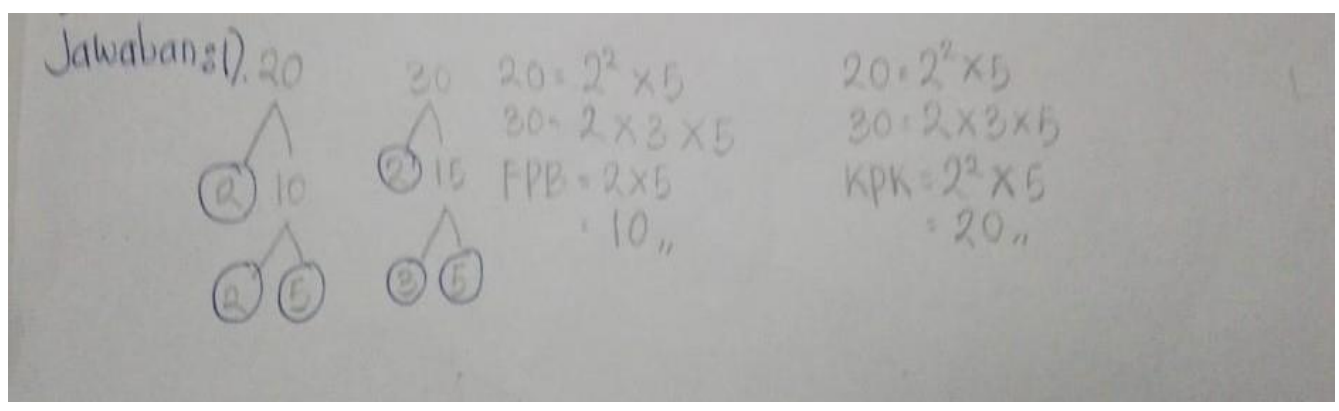

Gambar 2. Contoh jawaban siswa yang salah pada aspek merencanaka penyelesaian

Pada Gambar 2 terlihat bahwa siswa langsung mencari KPK dan FPB tanpa menuliskan unsur-unsur yang diketahui dan ditanyakan pada soal dengan alasan tidak perlu karena pasti diminta 
untuk mencari KPK atau FPB. Siswa sudah menger sudah mengerti dengan pertanyaan dan memahami cara menentukan FPB tetapi salah dalam menentukan KPK. Pada lembar jawaban siswa hanya menuliskan hasil dari FPB dan KPK dari bilangan-bilangan yang ada di soal. Siswa masih bingung dan tidak dapat merencanakan atau menentukan apakah untuk menyelesaikan soal tersebut harus memakai KPK ataukah FPB. Jadi siswa menuliskan keduanya dalam lembar jawaban. Untuk menentukan FPB hasilnya benar sedangkan untuk hasil KPK siswa menjawab salah karena lupa lagi bagaimana cara menentukan KPK dengan menggunakan faktorisasi aljabar. Setelah itu siswa bingung apa yang harus dilakukan selanjutnya dan menurut siswa soal yang berbentuk soal cerita sulit untuk dipahami.

\section{$>$ Analisis Kesalahan Jawaban Siswa pada aspek menyelesaikan masalah.}

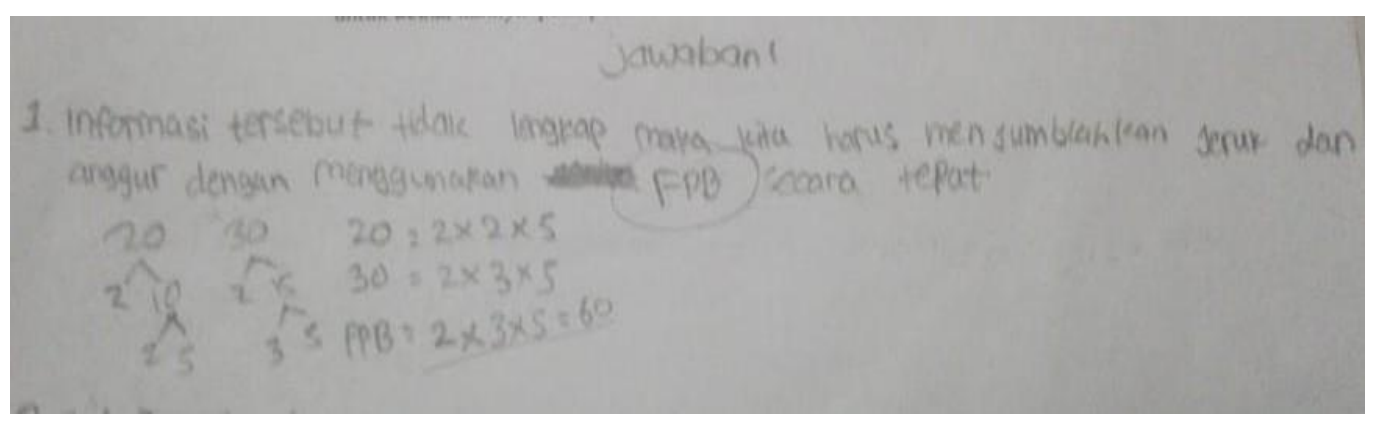

Gambar 3. Contoh jawaban siswa yang salah pada tahap menyelesaikan masalah

Pada Gambar 3 terlihat bahwa siswa sudah mengerti tentang pertanyaan pada soal. Siswa dapat memahami bahwa untuk menyelesaikan soal tersebut harus dengan menentukan FPB dari bilanganbilangan yang diketahui. Pada lembar jawaban siswa menentukan factor-faktor bilangan dengan menggunakan faktorisasi prima tapi pada saat menentukan FPB siswa menjawab salah. Ketika diwawancara, siswa bingung dan lupa bagaimana menentukan FPB karena yang diingat dalam menentukan FPB adalah semua factor ditulis dan siswa tidak menyukai soal yang berbentuk soal cerita karena pusing dan bingung. Siswa merasa tidak perlu menuliskan unsur-unsur yang diketahui karena sudah paham maksud dari soal tersebut. Dan siswa terburu-buru mengumpulkan lembar jawaban karena melihat teman-temannya sudah mengumpulkan lembar jawaban.

\section{Analisis Kesalahan Jawaban Siswa pada aspek memeriksa kembali}

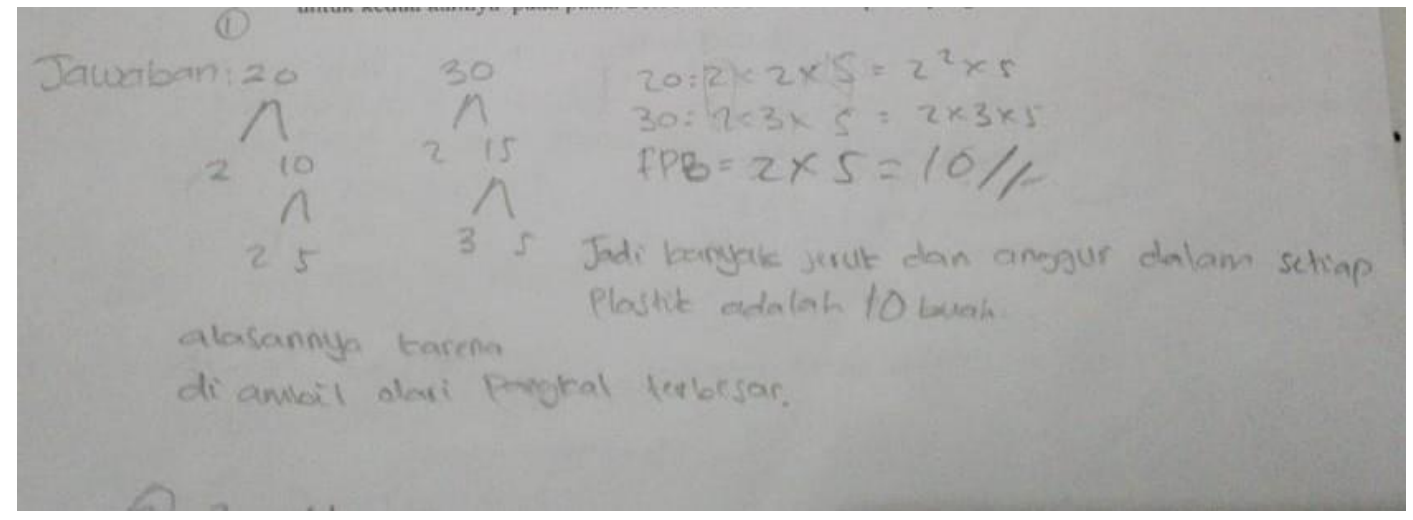

Gambar 4. Contoh jawaban siswa yang salah pada aspek memeriksa kembali 
Pada Gambar 4 terlihat bahwa siswa sudah memahami soal. Siswa sudah mampu merencanakan penyelesaian soal yaitu dengan cara menentukan FPB dari bilangan-bilangan yang diketahui pada soal. Dan siswa mampu menentukan factor-faktor bilangan dengan menggunakan faktorisasi prima sekaligus dapat menentukan FPBnya. Tapi pada saat tahap memeriksa kembali siswa langsung menyimpulkan bahwa banyaknya jeruk dan anggur dalam setiap plastik adalah 10 buah. Ketika diwawancara siswa bilang bahwa siswa tidak membaca kembali soal karena terburu-buru melihat teman-temannya sudah mengumpulkan lembar jawaban dan tidak memeriksa kembali apa sebenarnya yang ditanyakan pada soal tersebut. Siswa merasa tidak perlu menuliskan unsur-unsur yang diketahui dari soal tersebut karena merasa tidak perlu.

Berdasarkan analisis terhadap kesalahan- kesalahan jawaban, siswa tidak dapat mengidentifikasi permasalahan. Siswa langsung membuat alternatif penyelesaian masalah tanpa menganalisis permasalahan dengan baik, siswa langsung terpaku pada hasil akhir dan tidak memperhatikan proses pengerjaannya sehingga menimbulkan pemecahan masalah yang keliru. Siswa tidak menuliskan unsur-unsur yang diketahui dari soal karena merasa tidak perlu. Siswa langsung menjawab pada tahap merencanakan dan menyelesaikan masalah. Sebagian besar siswa yang mengalami kesulitan dalam menyelesaikan soal disebabkan mereka tidak memahami materi pendukung dari KPK dan FPB yaitu perkalian dan pembagian. Hasil penelitian ini sesuai dengan penelitian yang dilakukan Turmudi (2018) yang menyatakan untuk mencari penyelesaian masalah para siswa harus memanfaatkan pengetahuan mereka sebelumnya dan melalui proses ini mereka akan sering mengembangkan pemahaman matematika yang baru.

Ada beberapa siswa yang masih bingung dalam merencanakan penyelesaian soal, apakah memakai FPB ataukan KPK. Masih ada siswa yang belum bisa atau lupa bagaimana cara menentukan KPK dan FPB. Sebagian besar siswa tidak memeriksa kembali hasil pekerjaannya. Beberapa siswa juga ada yang tidak teliti dalam menyelesaikan soal karena ingin segera mengumpulkan tanpa memeriksa kembali jawaban. Hal ini sesuai dengan hasil penelitian yang dilakukan oleh Ariani (2018:33) yang mengatakan bahwa dalam siswa kurang teliti, lupa serta tergesa-gesa dalam mengerjakan soal, sehingga siswa keliru atau tidak sama sekali memeriksa hasil jawaban yang diperoleh. Siswa tidak menyukai soal yang berbentuk soal cerita karena dianggap sulit untuk dipahami sehingga gurupun jarang memberikan soal-soal pemecahan masalah. Hal ini sesuai dengan penelitian yang dilakukan Putra (2018:89) menyatakan bahwa siswa belum terbiasa mengerjakan soal-soal pemecahan masalah sehingga sulit untuk memahami informasi yang ada dalam soal.

\section{KESIMPULAN}

Berdasarkan hasil penelitian yang dilakukan pada siswa kelas VI Madrasah Ibtidaiyah Swasta Bongas 1 Kecamatan Cililin, dapat disimpulkan bahwa kemampuan pemecahan masalah matematis siswa tersebut masih rendah. Siswa belum terbiasa dengan soal-soal pemecahan masalah sehingga sulit memahami 
informasi pada soal. Siswa langsung membuat alternatif penyelesaian masalah tanpa menganalisis permasalahan dengan baik, siswa langsung terpaku pada hasil akhir dan tidak memperhatikan proses pengerjaannya sehingga menimbulkan pemecahan masalah yang keliru. Siswa kurang memahami tahap-tahap yang harus dilakukan dalam menyelesaikan soal pemecahan masalah, karena guru jarang memberikan soal pemecahan masalah. Siswa kesulitan dalam mengerjakan soal KPK dan FPB karena siswa tidak dapat melakukan operasi perkalian dan pembagian yang merukan materi prasyarat dari KPK dan FPB.

\section{DAFTAR PUSTAKA}

Akbar, P., Hamid, A., Bernard, M., \& Sugandi, A. I. (2018). Analisis kemampuan pemecahan masalah dan disposisi matematik siswa kelas xi sma putra juang dalam materi peluang. Jurnal Cendekia: Jurnal Pendidikan Matematika, 2(1), 144-153.

Ariani, S. (2017). Kemampuan Pemecahan Masalah Matematika Siswa pada Pembelajaran Matematika Menggunakan Strategi Abduktif-Deduktif di SMA Negeri 1 Insralaya Utara. Jurnal Elemen. 3(1), 25-34.

Bernard, M., Akbar, P., Ansori, A., \& Filiestianto, G. (2019, October). Improve the ability of understanding mathematics and confidence of elementary school students with a contextual approach using VBA learning media for Microsoft Excel. In Journal of Physics: Conference Series (Vol. 1318, No. 1, p. 012035). IOP Publishing.

Bernard, M., \& Senjayawati, E. (2019). Meningkatkan Kemampuan Koneksi Matematik Siswa SMP dengan Menggunakan Pendekatan Metaphorical Thinking Berbantuan Software Geogebra. Jurnal Mercumatika: Jurnal Penelitian Matematika dan Pendidikan Matematika, 3(2), 79-87.

Chotimah, S., Bernard, M., \& Wulandari, S. M. (2018, January). Contextual approach using VBA learning media to improve students' mathematical displacement and disposition ability. In Journal of Physics: Conference Series (Vol. 948, No. 1, p. 012025). IOP Publishing.

Chotimah, S., Ramdhani, F. A., Bernard, M., \& Akbar, P. (2019). Pengaruh Pendekatan Model-Eliciting Activities Terhadap Kemampuan Berpikir Kritis Matematik Siswa Smp Negeri Di Kota Cimahi. Journal on Education, 1(2), 68-77.

Fajriyah, L., Nugraha, Y., Akbar, P., \& Bernard, M. (2019). Pengaruh Kemandirian Belajar Siswa SMP Terhadap Kemampuan Penalaran Matematis. Journal on Education, 1(2), 288-296.

Hastratuddin. (2015). Mengapa Harus Belajar Matematika?. Medan : Perdana Publishing.

Isnaeni, S., Ansori, A., Akbar, P., \& Bernard, M. (2019). ANALISIS KEMAMPUAN KONEKSI MATEMATIS SISWA SMP PADA MATERI PERSAMAAN DAN PERTIDAKSAMAAN LINEAR SATU VARIABEL. Journal on Education, 1(2), 309-316. 
Nurhayati, N., \& Bernard, M. (2019). Analisis Kesulitan Siswa Dalam Pemecahan Masalah Matematik Siswa Kelas X SMK Bina Insan Bangsa Pada Materi Persamaan Dan Pertidaksamaan. Journal on Education, 1(2), 497-502.

Purba, N. E. (2017). Analisis Kemampuan Berpikir Kreatif Siswa Melalui Pemecahan Masalah pada Materi FPB dan KPK.

Puspitasari, I. W., Fauzan, G. A., \& Bernard, M. (2019). Penerapan PBL Dengan RME Berbatuan Software Geogebra Untuk Meningkatkan Kemampuan Berpikir Logis Matematik Siswa SMP. Journal on Education, 1(4), 679-687.

Putra, H. D. (2018). Kemampuan Pemecahan Masalah Matematis dan Self Confidence Siswa SMP. Supremum Journal of Mathematics Education. 2(2), 60-70.

Putra, H. D. (2018). Kemampuan Pemecahan Masalah Matematis Siswa SMP pada Materi Bangun Ruang. Jurnal Ilmiah Pendidikan Matematika. 6(2), 82-90.

Ramadhani, Sendi. (2012). Pembelajaran Matematika dengan Pendekatan Problem Posing untuk Meningkatkan Kemampuan Pemecahan Masalah dan Koneksi Matematis Siswa.

Ruseffendi, H. E. (2006). Pengantar kepada Membantu Guru Mengembangkan Kompetensinya dalam Pengajaran Matematika untuk Meningkatkan CBSA (Edisi Revisi ed.), Bandung : Tarsito.

Rustyani, N., Komalasari, Y., Bernard, M., \& Akbar, P. (2019). UPAYA MENINGKATKAN DISPOSISI DENGAN PENDEKATAN OPEN ENDED PADA SISWA SMK KELAS X-RPL B. Journal on Education, 1(2), 265-270.

Sumarmo, U. (2013). Kumpulan Makalah Berpikir dan Disposisi Matematika serta Pembelajarannya. Bandung : Jurusan Pendidikan Matematika FPMIPA-UPI.

Sumarmo, U. \& Hendriana, H. (2014). Penilaian Pembelajaran Matematika. $\quad$ Bandung: Reflika Aditama.

Timutius, F., Apriliani, N. R., \& Bernard, M. (2018). Analisis Kesalahan Siswa Kelas IX-G di SMP Negeri 3 Cimahi dalam Menyelesaikan Soal Pemecahan Masalah Matematik pada Materi Lingkaran. JPMI (Jurnal Pembelajaran Matematika Inovatif), 1(3), 305-312.

Ulvah, S. (2016). Kemampuan Pemecahan Masalah Matematis Siswa Ditinjau Melalui Model Pembelajaran SAVI dan Konvensional. Jurnal Riset Pendidikan, 2(2), 145-146.

Wiliawanto, W., Bernard, M., Akbar, P., \& Sugandi, A. I. (2019). Penerapan Strategi Pembelajaran Aktif Question Student Have Untuk Meningkatkan Kemampuan Berpikir Kritis Matematik Siswa SMK. Jurnal Cendekia: Jurnal Pendidikan Matematika, 3(1), 139-148. 